\title{
Sistem Informasi Akuntansi Pencatatan Kas Kecil Menggunakan Metode Extreme Programming
}

\author{
Adi Supriyatna ${ }^{1}$, Irmawati Carolina ${ }^{2}$, Wina Widiati ${ }^{3}$ \\ ${ }^{1}$ Universitas Bina Sarana Informatika \\ e-mail: 1 adi.asp@bsi.ac.id, ${ }^{2}$ irmawati.imc@bsi.ac.id, ${ }^{3}$ wina.wnw@bsi.ac.id

\begin{tabular}{ccc}
\hline Diterima & Direvisi & Disetujui \\
$01-07-2021$ & $01-09-2021$ & $01-10-2021$ \\
\hline
\end{tabular}

\begin{abstract}
Abstrak - Kas kecil merupakan dana yang ditetapkan oleh perusahaan untuk membiayai kegiatan operasional perusahaan secara rutin yang total pengeluarannya relatif lebih kecil dan dibayarkan secara tunai (Cash) tanpa menggunakan transfer bank atau cek. Dalam sebuah perusahaan pencatatan kas kecil baik kas masuk maupun kas keluar merupakan tanggung jawab bagian akunting, dalam pengelolaannya masih menggunakan sistem yang konvensional seperti menggunakan buku besar, microsoft excel dan sebagainya. Hal tersebut tentu saja dapat menimbulkan terjadinya kesalahan serta membutuhkan waktu yang lama. Tujuan dari penelitian ini adalah merancang sistem informasi akuntansi pencatatan kas kecil berbasis web yang efektif dan efisien. Metode yang digunakan pada penelitian ini berupa pengumpulan data yang meliputi observasi dan studi literatur dan metode pengembangan sistem menggunakan Extreme Programming yang terdiri dari tahapan perencanaan, perancangan, pengkodean dan pengujian. Hasil penelitian ini menunjukkan bahwa penggunaan sistem informasi pencatatan kas kecil dapat memberikan kemudahan kepada pengguna serta waktu yang efektif dan efisien dalam proses pencatatan kas kecil, selain itu dapat meminimalisir penyalahgunaan data.
\end{abstract}

Kata Kunci: Extreme Programming, Kas Kecil, Sistem Informasi Akuntansi.

\begin{abstract}
Petty cash is a fund set by the company to finance the company's regular operations whose total expenditure is relatively smaller and paid in cash without the use of bank transfers or checks. In a Petty cash recording company both cash in and out is the responsibility of the accounting part, in its management still using conventional systems such as using ledgers, microsoft excel and so on. This, of course, can lead to errors and take a long time. The goal of the study was to design an effective and efficient web-based petty cash recording accounting information system. The methods used in this study are data collection which includes observation and study of literature and system development methods using Extreme Programming consisting of planning, designing, coding and testing stages. The results of this study show that the use of petty cash recording information systems can provide convenience to users as well as effective and efficient time in the process of recording petty cash, in addition to minimizing data misuse.
\end{abstract}

Keywords: Extreme Programming, Petty Cash, Accounting Information System.

\section{PENDAHULUAN}

Kas kecil merupakan dana yang ditetapkan oleh perusahaan untuk membiayai kegiatan operasional perusahaan secara rutin yang total pengeluarannya relatif lebih kecil (Martha, Suwandi, \& Violeta, 2019) dan dibayarkan secara tunai (Cash) tanpa menggunakan transfer bank atau cek. Seperti pembiayaan listrik, pembiayaan telepon, pembiayaan materai, pembiaayan parkir dan tol (Achyani \& Velayati, 2020). Kas merupakan aktiva yang rawan karena mudah digalapkan dan dimanipulasi, karena kas memiliki karakter yang mudah dipindah tangan (Wardani \& Yuliastuti, 2021).

Sistem informasi akuntansi adalah untuk menghasilkan informasi yang bermanfaat untuk merencanakan, mengendalikan, dan mengoperasikan bisnis (Faizah, Susanti, \& Pujiastuti, 2020). Sistem informasi akuntansi penting untuk mendukung kelangsungan perkembangan suatu perusahaan, dengan salah satu informasi yang dibutuhkan oleh perusahaan yaitu informasi pengelolaan kas (Darwis, Wahyuni, \& Dartono, 2020). Operasional arus kas merujuk kepada pemasukan dan pengeluaran kas dengan melibatkan berbagai sumber daya yang ada di organisasi untuk menghasilkan pendapatan (Hartono \& Shauqy, 2020).

Dalam sebuah perusahaan pencatatan kas kecil baik kas masuk maupun kas keluar merupakan tanggung jawab bagian akunting, dalam pengelolaannya masih menggunakan sistem yang konvensional seperti menggunakan buku besar, microsoft excel dan sebagainya. Hal tersebut tentu saja dapat menimbulkan terjadinya kesalahan serta 
Artikel Ilmiah Sistem Informasi Akuntansi (AKASIA)

Volume 1 Nomor 2 Oktober 2021, pp. 139-146

E-ISSN: 2797 - 7277

https://jurnal.bsi.ac.id/index.php/akasia

membutuhkan waktu yang lama (Supriyono \& Muslimah, 2018).

Pada beberapa penelitian yang telah dilakukan menyatakan Penyusunan data pengelolaan kas kecil dapat diberikan lebih optimum, dan waktu untuk menginput dan mengevaluasi data kas kecil tersebut dapat diberikan lebih cepat karena sudah di dukung sistem yang terintegrasi (Murtiyono \& Iriano, 2015). Sistem informasi pengelolaan kas dapat mendukung pengguna sistem untuk bekerja lebih efektif dan efisien, dan dapat mengurangi tingkat kesalahan kas yang tidak sesuai dengan perencanaan (Supriyono \& Muslimah, 2018). sistem informasi dengan memanfaatkan teknologi yang digunakan dalam pengelolaan kas dapat dioperasikan secara maksimal untuk menghasilkan laporan pengelolaan kas serta dapat dipergunakan sebagai mestinya (Rusdi \& Andriani, 2021).

Tujuan dari penelitian ini adalah merancang sistem informasi akuntansi pencatatan kas kecil berbasis web yang efektif dan efisien.

\section{METODE PENELITIAN}

\section{Metode Pengumpulan Data}

Metode pengumpulan data yang dilakukan dalam penelitian ini yang pertama adalah observasi dengan cara melakukan pengamatan langsung untuk memperoleh informasi terkait sistem pengelolaan kas kecil pada perusahaan. Kedua adalah studi pustaka dengan cara mencari dan membaca literatur yang terkait dengan sistem pengelolaan kas melalui jurnal ilmiah yang sudah dipublikasi.

\section{Metode Pengembangan Sistem}

Untuk metode pengembangan sistem yang digunakan pada penelitian ini adalah Extreme Programming (XP) yang merupakan metode menggunakan pendekatan berorientasi objek dan juga sesuai jika tim dihadapkan dengan kebutuhan yang tidak jelas maupun terjadi perubahanperubahan kebutuhan yang sangat cepat (Carolina \& Supriyatna, 2019).



Sumber: (Carolina \& Supriyatna, 2019)
Gambar 1. Metode Extreme Programming

Tahapan yang terdapat pada metode Extreme Programming adalah sebagai berikut:

a. Perencanaan (Planning)

Kegiatan awal dalam pembangunan sistem yang meliputi menganalisa permasalahan, menganalisa kebutuhan sampai dengan penentuan jadwal pelaksanaan pembangunan sistem.

b. Perancangan (Design)

Pada tahapan ini dilakukan kegiatan perancangan pemodelan yang meliputi pemodelan sistem, pemodelan arsitektur menggunakan diagram Unified Modelling Language (UML), sampai dengan pemodelan data yang akan digunakan pada sistem.

c. Pengkodean (Coding)

Tahapan penerapan perancangan model kedalam bentuk antarmuka pengguna dengan menggunakan bahasa pemrograman. Pada penelitian ini bahasa pemrograman yang digunakan adalah PHP dengan framework Laravel 7. Sedangkan implementsi pemodelan data menggunakan MySQL sebagai sistem manajemen basis data.

d. Pengujian (Testing)

Tahapan pengujian dilakukan untuk memeriksa dan memvalidasi sistem yang telah dibangun untuk mengetahui kesalahan yang muncul saat sistem sedang digunakan. Metode pengujian yang digunakan pada penelitian ini adalah Blackbox Testing yang dilakukan terhadap bentuk form masukan untuk memastikan bahwa sistem sudah berjalan sesuai dengan fungsinya.

\section{HASIL DAN PEMBAHASAN}

\section{Perencanaan}

a. Identifikasi Masalah.

Berdasarkan hasil observasi yang telah dilakukan, maka permasalahan yang dapat diidentifikasikan adalah bukti transaksi penerimaan dan pengeluaran kas tidak tersimpan dengan baik sehingga kesulitan dalam pencarian dokumen apabila diperlukan kembali, pencatatan penerimaan dan pengeluaran kas masih dilakukan secara konvensional yang menyebabkan terjadi kemungkinan penyalahgunaan data serta waktu yang tidak efektif dan efisien dalam pengelolaan kas.

b. Analisa Kebutuhan Pengguna

Berdasarkan identifikasi masalah yang telah dilakukan oleh karena itu peneliti melakukan analisis kebutuhan pengguna dalam hal ini adalah admin petugas pengelola kas kecil sebagai berikut:

1) Admin melakukan login

2) Admin mengelola akun.

3) Admin mengelola kas masuk.

4) Admin mengelola kas keluar.

5) Admin mengelola buku besar. 
Artikel Ilmiah Sistem Informasi Akuntansi (AKASIA)

Volume 1 Nomor 2 Oktober 2021, pp. 139-146

E-ISSN: 2797 - 7277

https://jurnal.bsi.ac.id/index.php/akasia

2. Perancangan

a. Pemodelan Sistem Use Case Diagram

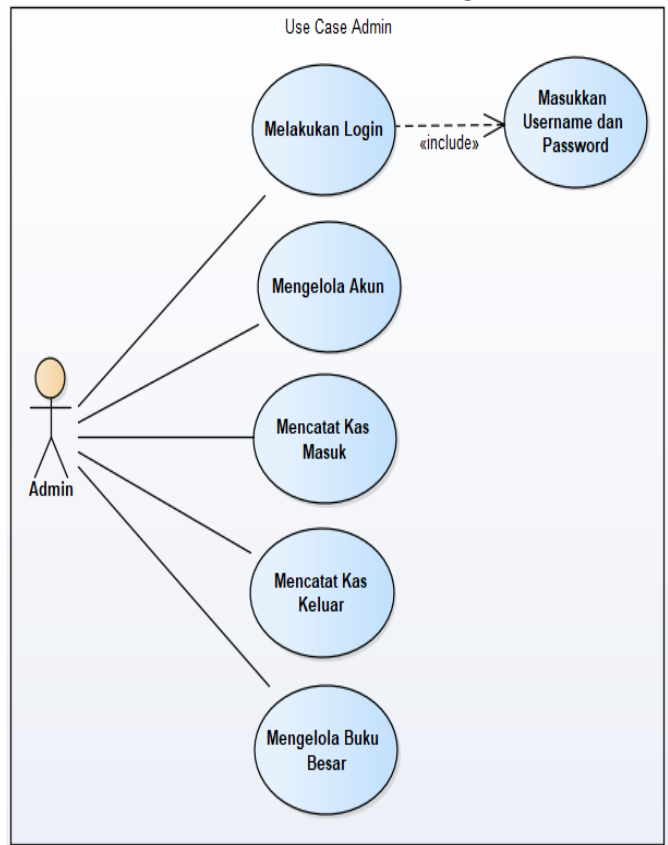

Sumber: (Hasil Penelitian, 2021)

Gambar 2. Use Case Diagram



Sumber: (Hasil Penelitian, 2021)

Gambar 3. Activity Diagram Melakukan Login

b. Pemodelan Sistem Activity Diagram

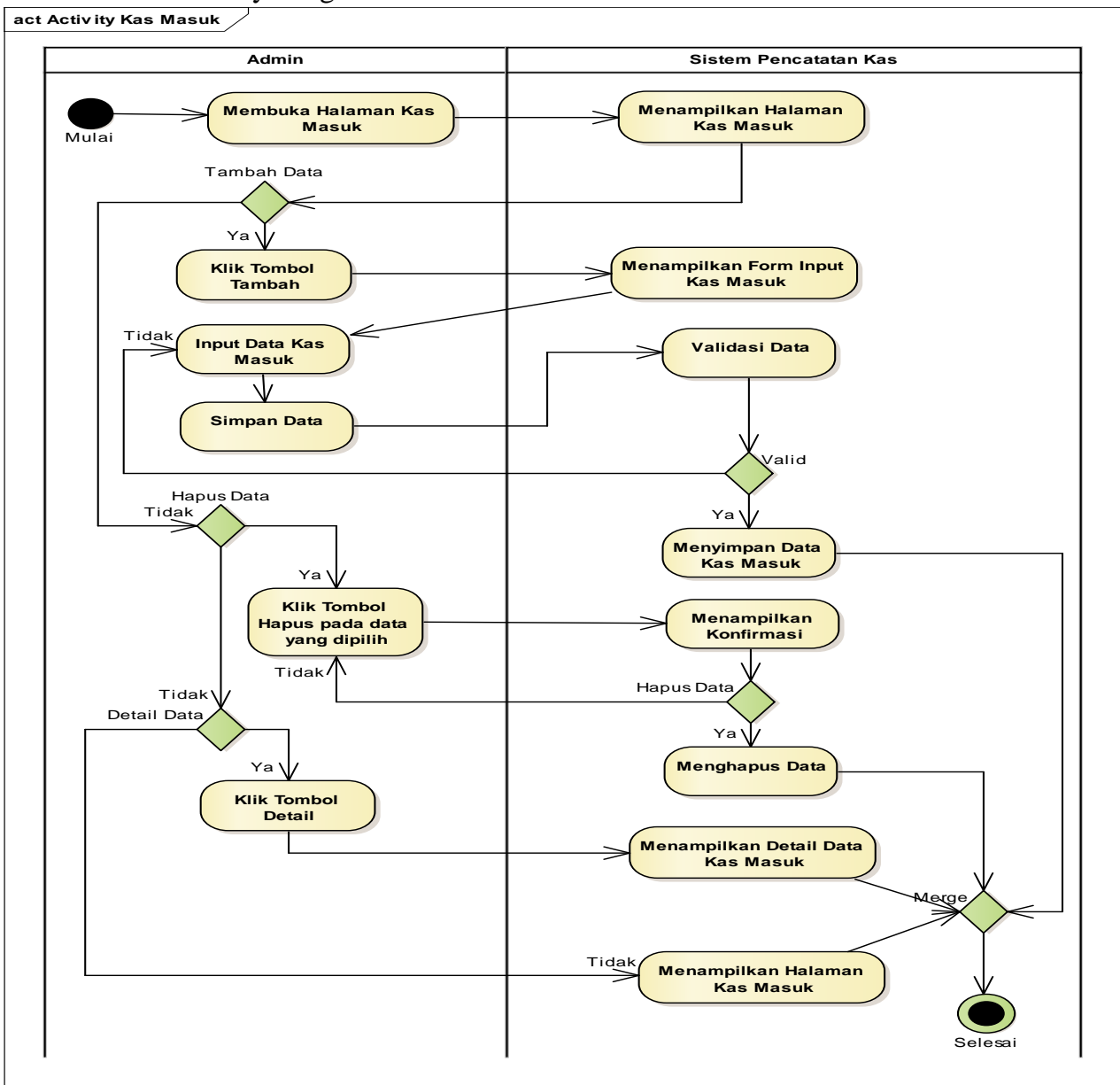


Artikel Ilmiah Sistem Informasi Akuntansi (AKASIA)

Volume 1 Nomor 2 Oktober 2021, pp. 139-146

E-ISSN: 2797 - 7277

https://jurnal.bsi.ac.id/index.php/akasia

Sumber: (Hasil Penelitian, 2021)

Gambar 4. Activity Diagram Mencatat Kas Masuk

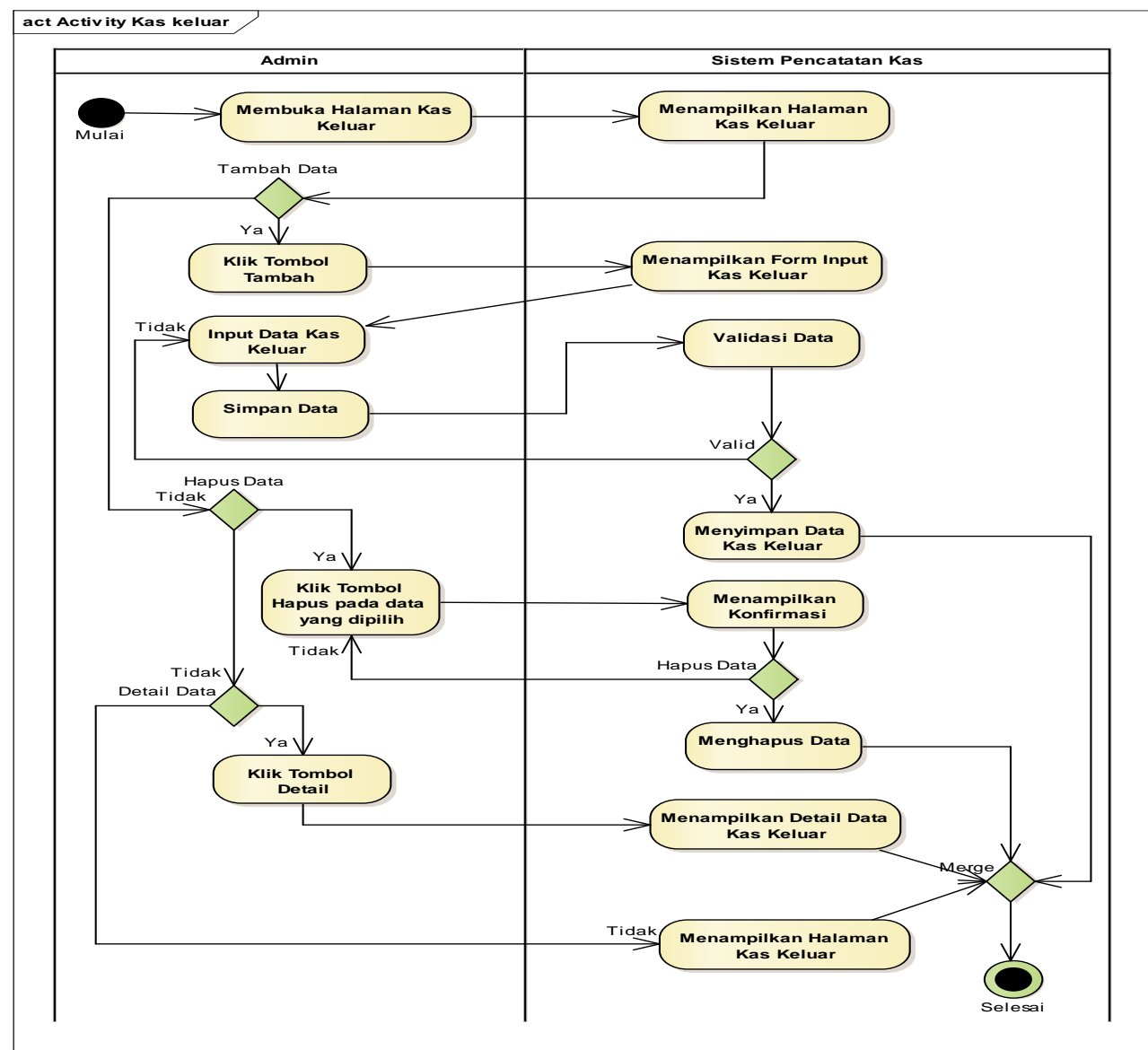

Sumber: (Hasil Penelitian, 2021)

Gambar 5. Activity Diagram Mencatat Kas Keluar

c. Pemodlean Arsitektur Deployment Diagram 
Artikel Ilmiah Sistem Informasi Akuntansi (AKASIA)

Volume 1 Nomor 2 Oktober 2021, pp. 139-146

E-ISSN: 2797 - 7277

https://jurnal.bsi.ac.id/index.php/akasia

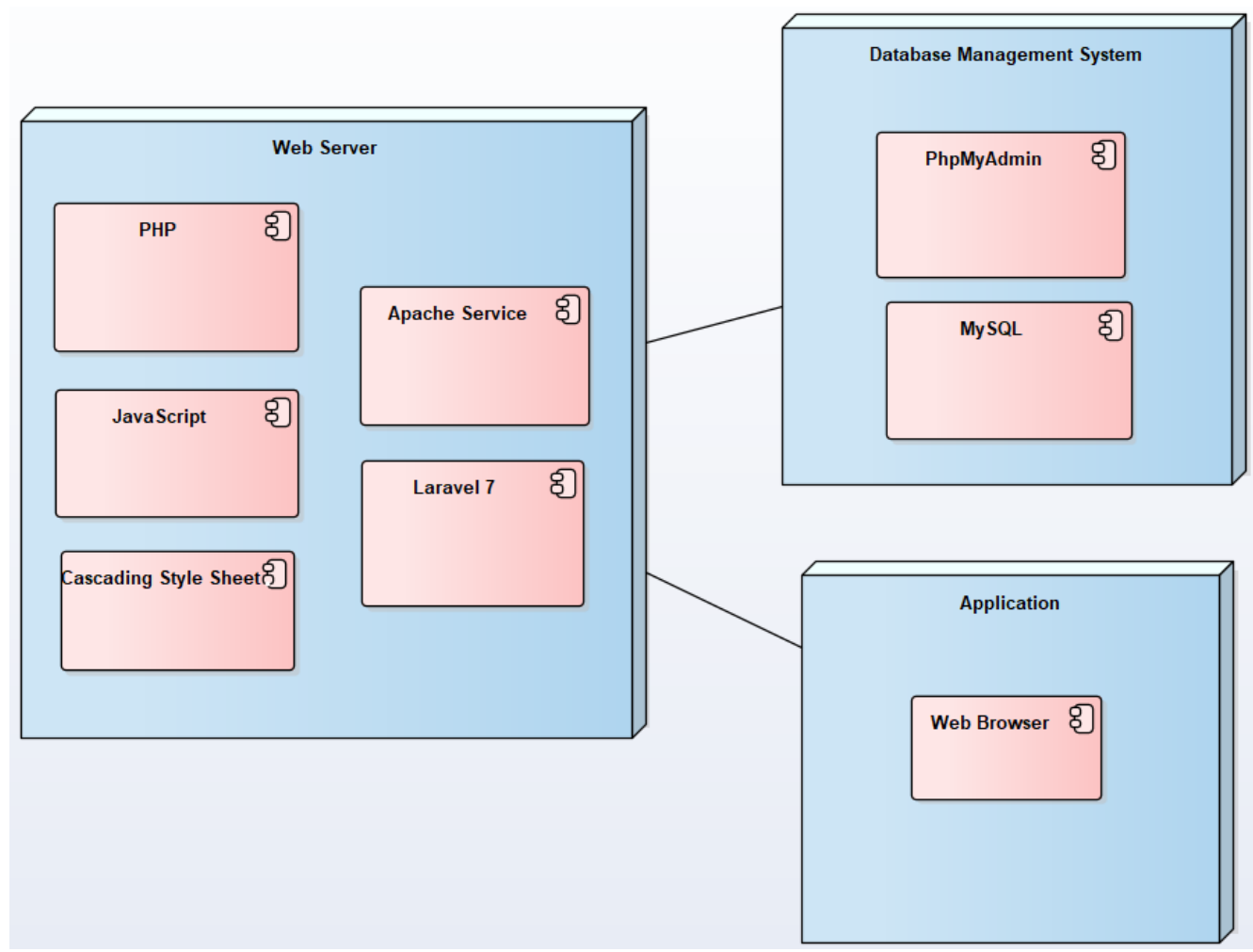

Sumber: (Hasil Penelitian, 2021)

Gambar 6. Deployment Diagram Sistem Pencatatan Kas Kecil

d. Pemodelan Data

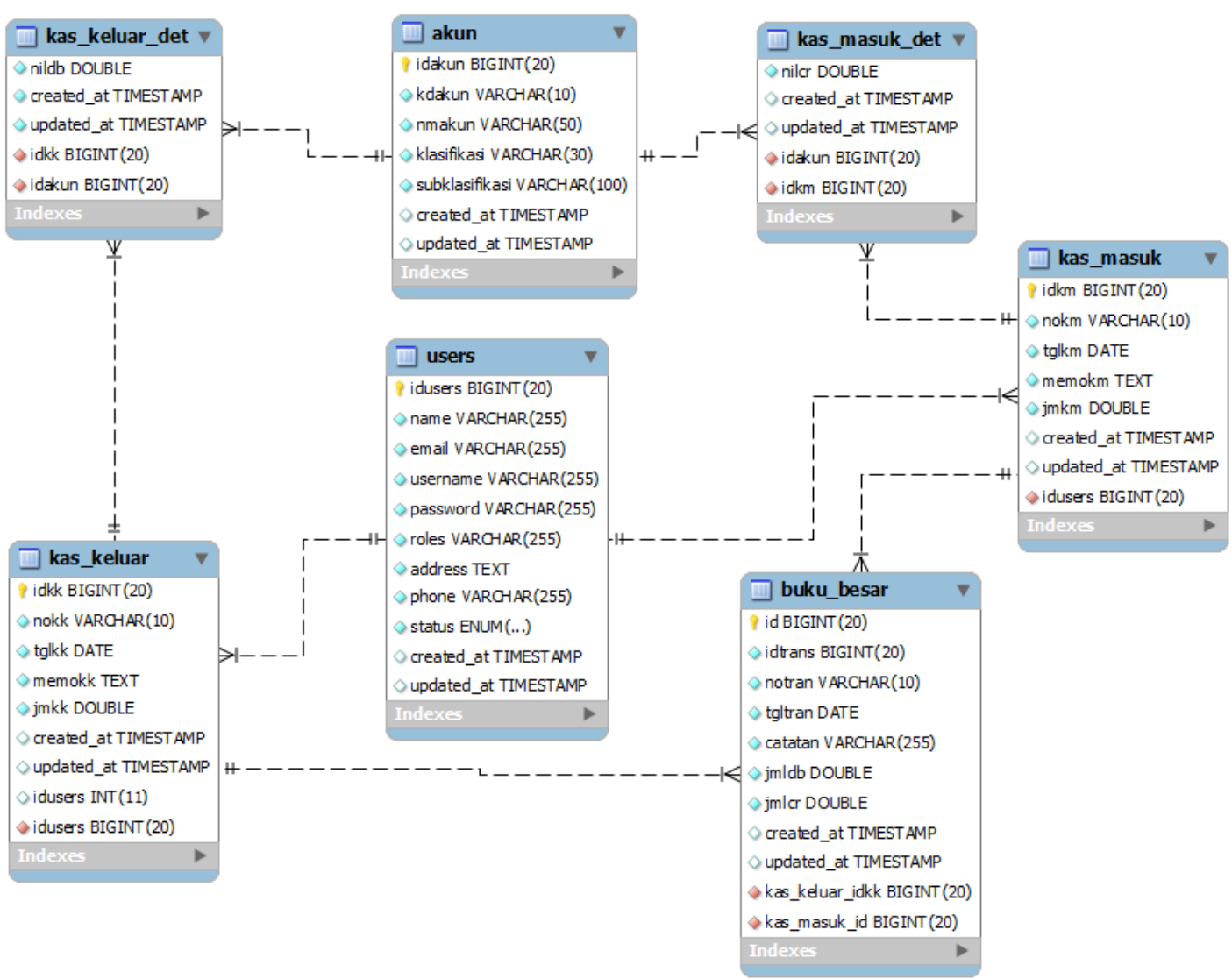

Sumber: (Hasil Penelitian, 2021)

Gambar 6. Model Data Sistem Pencatatan Kas Kecil 


\section{Pengkodean}

Tahapan ini merupakan kegiatan implementasi kode program menjadi sebuah tampilan antarmuka pengguna yang digunakan untuk melakukan proses pengolahan data maupun pencatatan kas kecil. Berikut ini tampilan antarmuka pengguna yang dihasilkan:

a. Halaman Login.

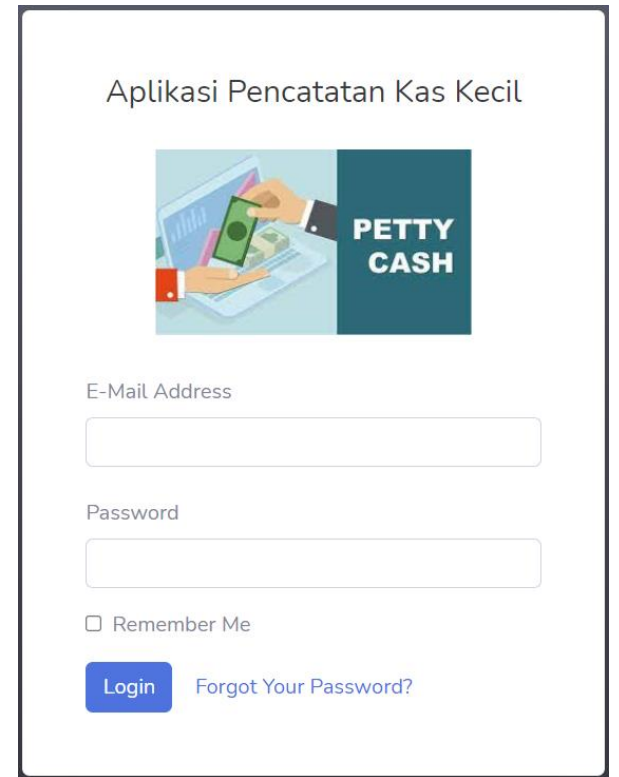

Sumber: (Hasil Penelitian, 2021)

Gambar 7. Tampilan Halaman Login

Halaman login tersebut digunakan untuk masuk ke halaman admin agar dapat mengelola pencatatan kas kecil yang dilakukan oleh Admin.

b. Halaman Data Akun

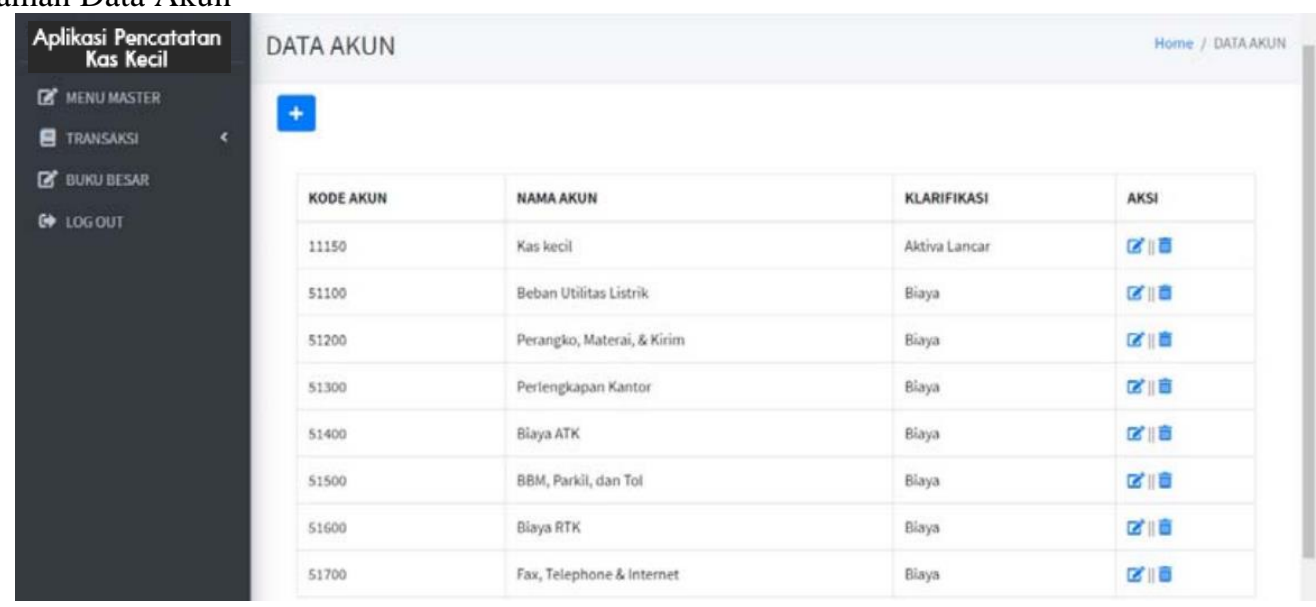

Sumber: (Hasil Penelitian, 2021)

Gambar 8. Tampilan Halaman Data Akun

Halaman data akun digunakan oleh admin untuk melakukan pengolahan data akun yaitu menambah, mengubah dan menghapus data.

c. Halaman Data Kas Masuk. 
Artikel Ilmiah Sistem Informasi Akuntansi (AKASIA)

Volume 1 Nomor 2 Oktober 2021, pp. 139-146

E-ISSN: 2797 - 7277

https://jurnal.bsi.ac.id/index.php/akasia

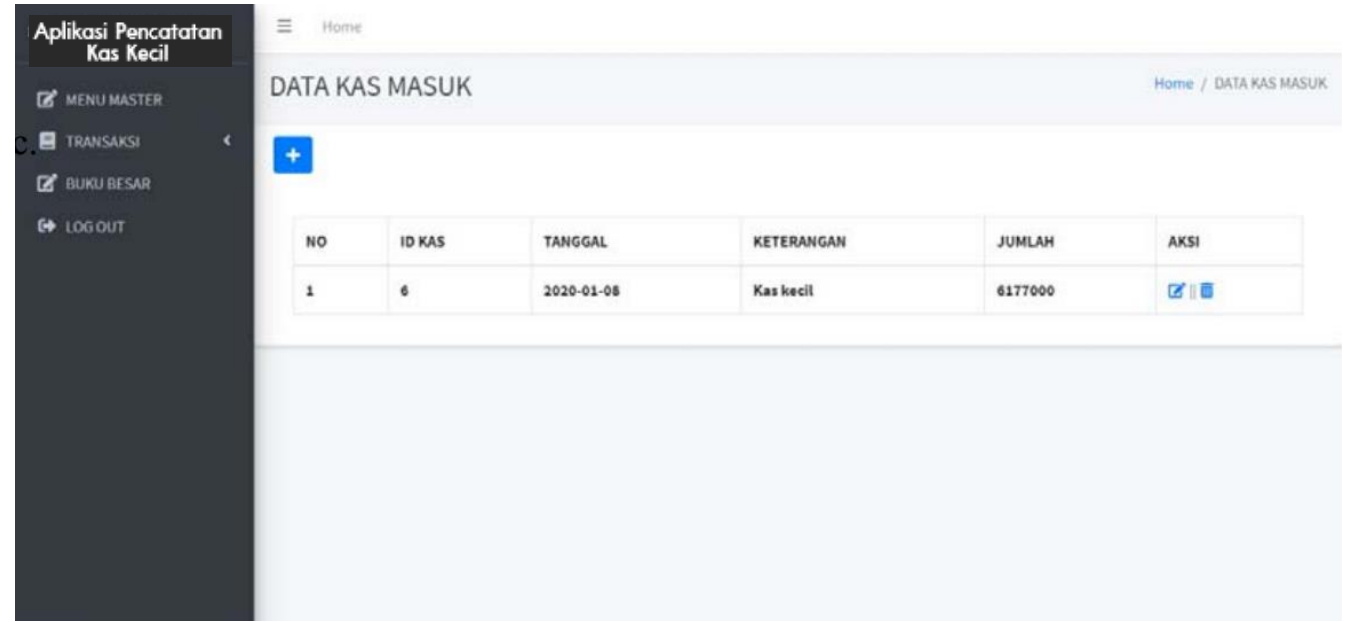

Sumber: (Hasil Penelitian, 2021)

Gambar 9. Tampilan Halaman Data Kas Masuk

Halaman ini digunakan untuk melakukan pengolahan data berupa penambahan, pengubahan dan penghapusan data kas masuk yang dilakukan oleh admin berdasarkan transaksi yang telah dilakukan.

d. Halaman Data Kas Keluar.

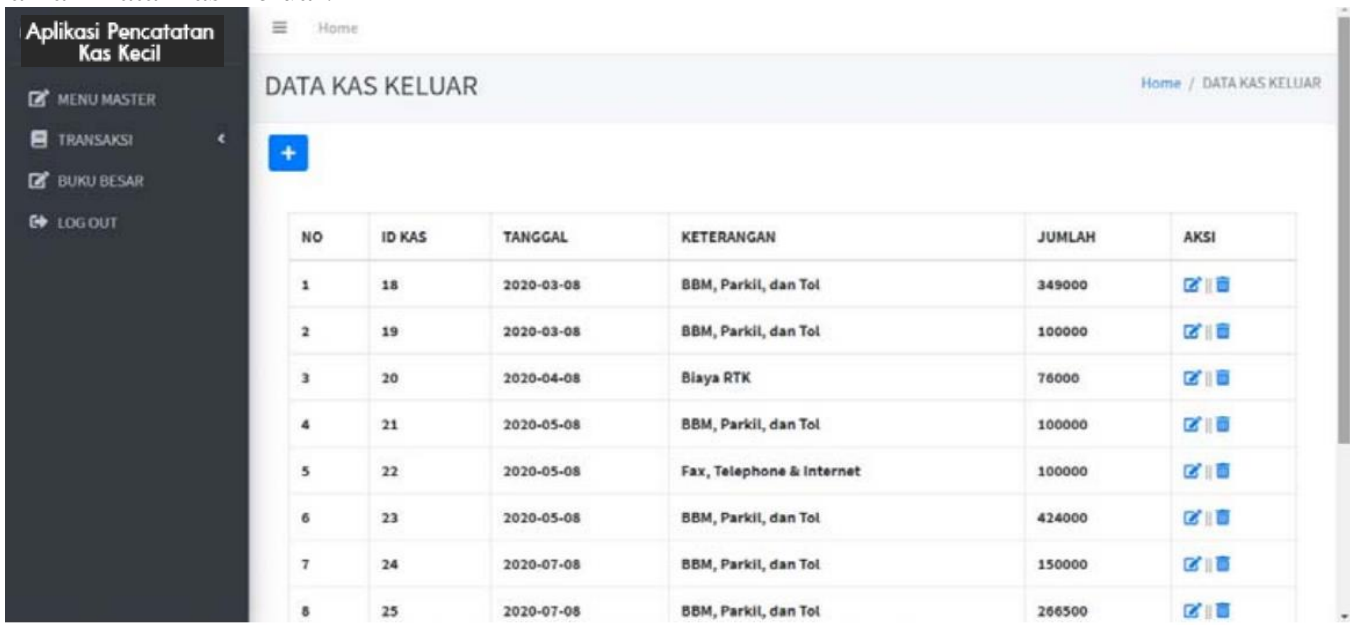

Sumber: (Hasil Penelitian, 2021)

Gambar 10. Tampilan Halaman Data Kas Keluar

Halaman ini digunakan untuk melakukan pengolahan data berupa penambahan, pengubahan dan penghapusan data kas keluar yang dilakukan oleh admin berdasarkan transaksi yang telah dilakukan.

e. Halaman Data Buku Besar

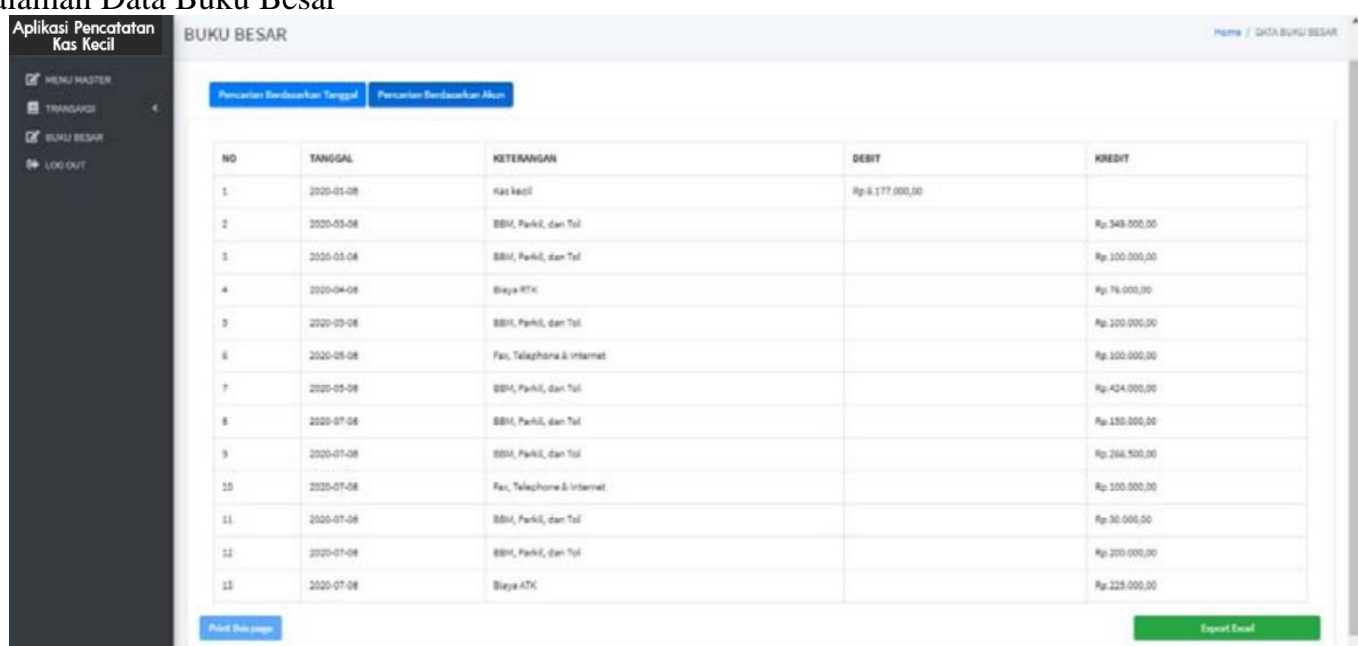

Sumber: (Hasil Penelitian, 2021) 
Gambar 11. Tampilan Halaman Data Buku Besar

Halaman ini digunakan untuk melakukan menampilkan data buku besar sesuai dengan transaksi yang telah dilakukan, serta dapat mengubah bentuk data menjadi format file Microsoft Excel.

\section{Pengujian}

Pengujian yang dilakukan dalam penelitian ini bertujuan untuk memastikan bahwa semua fitur yang terdapat pada sistem informasi pencatatan kas kecil berjalan dengan baik, sesuai dengan fungsi dan format yang ditentukan serta memenuhi kebutuhan pengguna. Berdasarkan hasil pengujian yang telah dilakukan menggunakan metode BlackBox Testing terhadap fitur yang ada, dapat disimpulkan bahwa semua fitur atau modul yang terdapat pada sistem pencatatan kas kecil sudah sesuai dengan fungsi dan format yang ditentukan serta sudah sesuai dengan kebutuhan pengguna.

\section{KESIMPULAN}

Berdasarkan hasil penelitian yang telah dilakukan maka kesimpulan yang dapat diambil adalah dengan dukungan teknologi informasi berupa sistem informasi dalam pencatatan kas kecil terbukti dapat membantu memberikan kemudahan kepada pengguna khususnya bagian akunting dalam proses pencatatan kas kecil, dapat terhindar dari penyalahgunaan data. Serta semua data transaksi yang berhubungan dengan kas kecil dapat tersimpan dengan baik dan rapih didalam basis data sehingga pencarian data dan dokumen dapat dilakukan dengan mudah.

Untuk penelitian berikutnya akan dilakukan pengembangan terhadap sistem ini dengan menambahkan beberapa fitur serta mengintegrasikan dengan sistem yang lain.

\section{REFERENSI}

Achyani, Y. E., \& Velayati, A. (2020). Analisa dan Implementasi Sistem Informasi Pengeluaran Kas Kecil Pada PT. Bank Bukopin Berbasis Web. Paradigma - Jurnal Komputer Dan Informatika, 22(1), 47-54. https://doi.org/10.31294/p.v22i1.7171

Carolina, I., \& Supriyatna, A. (2019). Penerapan Metode Extreme Programming Dalam Perancangan Aplikasi Perhitungan Kuota Sks Mengajar Dosen. Jurnal IKRA-ITH Informatika, 3(1), 106-113. https://doi.org/10.31227/osf.io/se6f9

Darwis, D., Wahyuni, D., \& Dartono, D. (2020). Sistem Informasi Akuntansi Pengolahan Dana Kas Kecil Menggunakan Metode Imprest Pada PT Sinar Sosro Bandarlampung. Jurnal
Teknologi Dan Sistem Informasi (JTSI), I(1), 15-21.

Faizah, S., Susanti, N. R., \& Pujiastuti, E. (2020). Sistem Informasi Pengeluaran Kas Pada Yayasan Dana Pensiun Askrida Berbasis Web. INFORMATION MANAGEMENT FOR EDUCATORS AND PROFESSIONALS, 4(2), 123-132.

Hartono, S. B., \& Shauqy, A. F. (2020). Pengembangan Sistem Informasi Arus Kas Dengan Metode Sdlc (System Development Life Cycle) Pada Madin Al-Junnah. ISOQUANT: Jurnal Ekonomi, Manajemen Dan Akuntansi, 4(1), 1-16. https://doi.org/10.24269/iso.v4i1.337

Martha, D., Suwandi, S., \& Violeta, V. (2019). Perancangan Sistem Informasi Akuntansi Pengeluaran Dana Kas Kecil Pada Pt Graha Sarana Duta ( Telkom Property ) Information Systems Design Accounting of Small Cash Withdrawal Funds At Pt Graha Sarana Duta ( Telkom Property ). Sigma-Mu, 11(2), 13-22.

Murtiyono, R., \& Iriano, P. (2015). Pembuatan Sistem Informasi Akuntansi Pengelolaan Kas Kecil Dengan Menggunakan Metode Dana Tetap. Jurnal Komputer Akuntansi, 11(2), 211.

Rusdi, I., \& Andriani, F. (2021). Sistem Informasi Pencatatan Arus Kas ( SIPAS ) Pada PKBM Negari 23 Kebon Melati Jakarta Menggunakan Model Waterfall. Smart Comp, 10(2), 67-73.

Supriyono, S., \& Muslimah, E. (2018). Perancangan Sistem Informasi Manajemen Kas Berbasis Web Studi Kasus: RS dr. Etty Asharto Batu. Matics, 10(1), 21-25. https://doi.org/10.18860/mat.v10i1.4302

Wardani, A. V. B., \& Yuliastuti, R. (2021). ANALISIS DAN PERANCANGAN SISTEM INFORMASI AKUNTANSI PENJUALAN DAN PENERIMAAN KAS ( ONLINE SHOP KANTONG ASI BAABAA BAGBIT ) pada kelangsungan masa depan perusahaan dagang Baabaa dan Bagbit yang menjual berbagai. Jurnal Ilmiah Sistem Informasi, 1(01), 57-63. https://doi.org/10.46306/sm.v1i1 